\title{
Isidore and the gens Gothorum
}

\author{
Walter Pohl and Philipp Dörler ${ }^{1}$
}

[Accepted manuscript of the article published in: Isidore de Séville et son temps. Antiquité Tardive 23 (2015) 133-142].

\begin{abstract}
What was the significance of the gens Gothorum in Isidore's writings, and in the world in which he lived? The present article discusses the Historia Gothorum, the Etymologies, the Acts of Toledo III and IV, and in what ways the Goths appear in these texts. Gothic rule, and a political world of gentes, had come to seem natural. Isidore promotes a vision of Catholic unity of Spania and its different peoples under Gothic rule, but maintains the distinctiveness of the Goths as a people. Their victories and their Catholic conversion now legitimize their rule over the entire peninsula, for which they should seek the consensus of the bishops as representatives of the Spanish patria. This vision is not directed at the obliteration of differences between the Goths and the other populi of Spain, but at a balance of interests based on Christian values. Isidore was aware of the problems of Gothic rule in the past, and hoped to contribute to their more responsible conduct in the future.
\end{abstract}

Many scholars underline that Isidore's historical work is "virulently pro-Visigothic", written "to underline Visigothic superiority over their political opponents". ${ }^{2}$ Indeed, the impression that Isidore's History of the Goths in particular is an unambiguous "glorification of the Visigoths" 3 , "une apologie de la nation gothique"4 easily emerges from the text. "Isidore celebrated the Spanish Goths", as Walter Goffart put it; he saw Isidore’s History as the earliest of "the first national histories", together with Fredegar, the Origo gentis Langobardorum and Bede’s Ecclesiastical History. ${ }^{5}$ Marc Reydellet called Isidore's History "le premier monument de l'histoire nationale espagnole". ${ }^{6}$ Jacques Fontaine was slightly more subdued about Isidore's praise of the Goths, but still links the author's historiographic project closely with an apology of the Goths as rulers of Spain: "Grâce à Isidore de Séville, voici les Wisigoths solidement installés à leur place, dans l’histoire de l’Espagne par l’Eloge de l’Espagne, dans l'histoire de Rome par le traité 'De l’origine des Goths', comme ils

\footnotetext{
${ }^{1}$ The research leading to these results was conducted in the context of the European Research Council in the Seventh Framework Programme (FP7/2007-13) under the ERC grant agreement No. 269591 and the Austrian Research Fund (FWF) Project P27804-G16. We are grateful to Molly Lester, Helmut Reimitz and Graeme Ward for corrections and comments.

2 J. Wood, The Politics of Identity in Visigothic Spain: Religion and Power in the Histories of Isidore of Seville, Leiden, 2012 (Brill's Series on the Early Middle Ages, 21), p. 5.

${ }^{3}$ R. L. Stocking, Bishops, Councils and Consensus in the Visigothic Kingdom, 589-633, Michigan, 2001, p. 133.

${ }^{4}$ C. Martin, La géographie du pouvoir dans l'Espagne visigothique, Lille, 2003, p. 18.

${ }^{5}$ W. Goffart, The Narrators of Barbarian History: A.D. 550-800. Jordanes, Gregory of Tours, Bede, and Paul the Deacon, Princeton, 1988, p. 245. Goffart contrasts these 7th- and early 8th-century histories, perhaps too starkly, with the earlier works by Jordanes and Gregory of Tours.

${ }^{6}$ M. Reydellet, "Les intentions idéologiques et politiques dans la Chronique d’Isidore de Séville”, in Mélanges d'archéologie et d'histoire, 82, 1970, p. 363-400, at p. 363; id., La Royauté dans la littérature latine de Sidoine Apollinaire à Isidore de Séville, Rome, 1981 (BÉFAR, 243), p. 505-597.
} 
l'avaient été dans l'histoire universelle, païenne et chrétienne, par sa Chronique."7 Isidore "is less exaggerated than Jordanes in his praise of the Goths”, was J. N. Hillgarth's judgement. ${ }^{8}$

There certainly is no lack in recent substantial studies about Isidore's intentions and outlook. They have underlined the "Isidorian renaissance" and its political perspectives, ${ }^{9}$ Isidore's role as a "tutor" of the Kingdom of Toledo, ${ }^{10}$ his attempt "to justify the contemporary dominance of the Visigoths in Spain" by a negative presentation of the empire and the other gentes, ${ }^{11}$ or the paradoxical effect of his search for an ideal consensus where practical consent could hardly be achieved. ${ }^{12}$ In all of these studies, the role of the Goths was and had to be seen as one element in the political and cultural development of seventh-century Spain. But what exactly was the significance of the gens Gothorum in this context? The concept of a "Hispano-Gothic nation" to which Isidore devoted his "national history", so forcefully expressed in some of the scholarly literature, is unhelpful for a nuanced understanding. ${ }^{13}$ As Isabel Velázquez has shown, the idea that the Gothic monarchy represented the origin of the Spanish nation was a highly teleological and ideological construction, which could come in the way of a more refined historical analysis. ${ }^{14}$ Suzanne Teillet has claimed that by the time of the Third Council of Toledo (589), gens Gothorum already referred to the entire population of Goths and Hispano-Romans. ${ }^{15}$ However, it hardly seems that Isidore, regardless of how deeply he was involved in Gothic politics, would have considered himself a Goth. The Goths could be regarded, in Isidore's famous image, as betrothed to the Spania; ${ }^{16}$ but as we will try to show, they remained a separate entity. The boundaries between the Goths and the Spanish had of course become blurred, and if the Gothic kingdom had survived, it may at some point have been inhabited by a majority of Spanish-speaking Godos, analogous to the Romancespeaking Français.Yet in the seventh century the Goths still represented a ruling minority in a country mostly inhabited by Spani, by other ethnic groups and by people whose identity was prevalently rooted in their cities or regions.

\footnotetext{
${ }^{7}$ J. Fontaine, Isidore de Séville et la culture classique dans l'Espagne wisigothique, 2 vol., Paris, 1959, p. 232.

${ }^{8}$ J. N. Hillgarth, The Visigoths in History and Legend, Toronto, 2009 (ST, 166), p. 31.

${ }^{9}$ Fontaine, Isidore. See also Y. Hen, Roman Barbarians. The Royal Court and Culture in the Early Medieval West, Basingstoke, 2007, p. 141-152.

${ }^{10}$ Fontaine, Isidore, p. 129-164.

${ }^{11}$ Wood, Politics of Identity, p. 241; id., "Religiones and gentes in Isidore of Seville’s Chronica maiora. The Visigoths as a chosen people”, in W. Pohl/G. Heydemann (dir.), Post-Roman Transitions: Christian and Barbarian Identities in the Early Medieval West, Turnhout, 2013, p. 125-168.

${ }^{12}$ Stocking, Bishops.

${ }^{13}$ S. Teillet, Des Goths à la nation gothique: Les origines de l'idée de Nation en Occident du Ve au VIIe siècle, Paris, 1984.

${ }^{14}$ I. Velázquez Soriano, "Pro patriae gentisque Gothorum statu (4th Council of Toledo, Canon 75, a. 633)”, in H.-W. Goetz/J. Jarnut/W. Pohl (dir.), Regna and gentes. The Relationship between Late Antique and Early Medieval Peoples and Kingdoms in the Transformation of the Roman World, Leiden, 2003, p. 161-217. For the problems of the concept of pre-modern nations in general, see I. Afanasiev (dir.), Identity, Ethnicity and Nationhood before Modernity: Old Debates and New Perspectives, with the contribution of W. Pohl, "What did ethnicity mean in the Early Middle Ages?”, forthcoming.

${ }^{15}$ Teillet, Goths à la nation Gothique, p. 540; for a critique, Velázquez, "Pro patriae”, p. 168.

${ }^{16}$ Isidore, Historia Gothorum (HG-M), dir. T. Mommsen, MGH AA, 11, Berlin, 1894, p. 267-303, Prologue (De laude Spaniae), p. 267. For the English translations used in this paper see: Isidore, History of the Kings of the Goths $(H G-W)$, trans. K. B. Wolf, Conquerors and Chroniclers of Early Medieval Spain, 2nd ed., Liverpool, 1999, p. 79-110. Spanish edition: Las historias de los godos, vándalos y suevos de Isidoro de Sevilla, dir. C. Rodríguez Alonso, León, 1975.
} 
Therefore, if we want to know what the gens Gothorum meant to Isidore, it is useful to differentiate between a number of issues that played a role in his views about the Gothic regimes, past and present. The first, and politically most incisive of these issues, are Isidore's perceptions of the kingdom (see the contributions by Salvador Rus Ruffino, Hervé Inglebert and Gerd Kampers, in this volume). That includes his personal relations, mainly with the kings Sisebut, Swinthila and Sisenand; but also ideas about the legitimacy of Visigothic kingship and the Goths' exclusive privilege to rule; pragmatic problems of increasing the inner stability of the regime, as they came to the fore at the Fourth Council of Toledo (633); the historical succession of empires and kingdoms, with its implications for eschatological perspectives; and general moral reflections on good and bad kingship. The second issue is the patria, Spania, which receives such emphatic praise from his pen in the Laus Spaniae attached to the second version of his History (produced unter Suinthila in 625/26, the earlier version is dated to 615). Did the majority of its inhabitants regard themselves as Spani, or were regional and civic identities much more important? The peninsula was also the theatre of Isidore's contemporary historical accounts, in a much more restricted fashion than in the Chronicle of John of Biclaro a generation before him.

The third issue is the identity of the Goths as a gens, and its changes over time. This point is inseparable from their relationship with other gentes, and with the Romans. Not by coincidence, Isidore relates the history of the Goths in the context of briefer accounts of that of the Vandals and Sueves. Isidore, like many of his contemporaries, perceived the political landscape as a world of gentes, and of their polities. Quite exceptionally, in his case, we have good evidence about his concepts of the gentes, discussed, most explicitly, in Book IX of his Etymologies. We will use the modern concept of 'ethnicity' to describe this notional division of the world according to distinctions between peoples, and of 'ethnic identity' where a sense of Gothic, or other affiliation and 'groupness' is suggested by the texts. ${ }^{17}$ 'Ethnic' does not indicate actual common origin. Furthermore, ethnicity does not denote a particularly barbarian mode of identification as opposed to more universal Roman and Christian forms of community. What this article is concerned with is its changing significance in a Christian context, rather than an often-assumed progress from an ethnic ("gentile”) to a territorial polity. ${ }^{18}$

There is a fourth issue involved in Isidore's attitudes towards the Goths, and that is their long history as champions of the 'Arian', Homoian creed. For the present, Isidore could rely on the firm Catholic basis of the monarchy established at the Third Council of Toledo; yet, that had only happened when Isidore was a young man, and the Arian past posed a problem in his histories. One delicate case shows that his priorities were not always on the Catholic side: the

\footnotetext{
${ }^{17}$ W. Pohl, "Introduction - Strategies of Identification: A Methodological Profile”, in id,/G. Heydemann (dir.), Strategies of Identification: Ethnicity and Religion in Early Medieval Europe, Turnhout, 2013, p. 1-64.

${ }^{18}$ D. Claude, “Gentile und territoriale Staatsideen im Westgotenreich“, Frühmittelalterliche Studien, 6, 1972, p. 1-38; G. Kampers, Geschichte der Westgoten, Paderborn, 2008, p. 275-278; W. Pohl, "Christian and Barbarian Identities in the Early Medieval West: Introduction”, in id./G. Heydemann (dir.), Post-Roman Transitions: Christian and Barbarian Identities in the Early Medieval West, Turnhout, 2013, p. 1-46.
} 
revolt of Hermenegild, who had become a Catholic, against his Arian father, King Leovigild, in the 580s. Hermenegild had been based as a sub-king in Seville, where Isidore's brother Leander was bishop, who had been involved with the king's conversion and revolt, and even gone to Constantinople as an envoy on his behalf. ${ }^{19}$ Threatened by Byzantine intervention, Leovigild conquered Seville, and Hermenegild was first exiled and then murdered. In the eyes of Pope Gregory I, he was a martyr of the Catholic cause-Gregory's extensive account in the Dialogues does not mention his rebellion, but simply the persecution by his father because of his conversion to the Catholic side. ${ }^{20}$ Isidore, on the contrary, left out the young king's conversion and treats him as a mere rebel, in a half sentence listed among Leovigild's "brilliant” military achievements. ${ }^{21}$ In the following chapter, Isidore harshly judged Leovigild's "Arian perfidy" and "persecution against the Catholics"; he "sent many bishops into exile, and took away many of the revenues and privileges of the churches". 22 But he drew no connection to Hermenegild's revolt. Isidore glossed over the case, probably because rebellion against the king, and not least, of the son against the father, did not seem acceptable even in defence of the Catholic cause; but maybe also because it was not well-remembered in Seville, and embarrassing to the family because Isidore's brother had been deeply involved in the plot, and surely suffered some of the consequences of the revolt's failure. ${ }^{23}$ The case indicates a hidden conflict of loyalty and identity; Isidore's condensed historiographic style, however, makes it hard to identify such inner tensions, conflicts of interest or alternative options.

Regnum, patria, gens and Christian religion, the four basic modes of identification in Isidore's Spain, ${ }^{24}$ were deeply entangled, and indeed it was Isidore's intention to link them as closely as possible, and 'write out' their contradictions. Through Toledo III, the gens Gothorum had embraced the Catholic cause. One programmatic phrase in the canons of the Fourth Council of Toledo puts it into a nutshell: Corroboret Christi gloria regnum illius gentis Gotorum in fide catholica. ${ }^{25}$ The regnum is the rule of the Goths as a gens, protected by Christ in its Catholic faith. Toledo V (636) and VI (638) established Gothic origin as a prerequisite for becoming king. ${ }^{26}$ The gens as a whole was perceived as having a hereditary claim to the

\footnotetext{
${ }^{19}$ For the events, see R. Collins, Visigothic Spain, 409-711, Oxford/Malden, 2004, p. 56-58; Kampers, Geschichte der Westgoten, p. 173-180. The most extensive account is found in Gregory of Tours, Libri Historiarum X, dir. B. Krusch/W. Levison, MGH SS rer. Merov., 1,1, Hannover, 1937, 5, 38, p. 243-245; 6, 18 , p. 287-288; 6, 29, p. 295-297; 6, 34, p. 304-305; 6, 40, p. 310-313; 6, 42, p. 314.

${ }^{20}$ Gregory the Great, Dialogi Libri IV de vita et miraculis patrum Italicorum, dir. A. de Vogüé, Paris, 1979 (SC, 260), 3, 31, p. 386: Corpus illius, ut videlicet martyris, iure a cunctis fidelibus venerari debuisset.

${ }^{21}$ Isidore, Chronica, dir. J. C. Martín, Turnhout, 2003 (CCSL, 112), 2, 405, p. 198: Gothi per Ermenegildum Leuuigildi regis filium bifarie divisi mutua caede vastantur; HG-W, c. 49, p. 102: "Then he laid siege to his son Hermenegild, who was in revolt against his dominion, and defeated him.”

${ }^{22} H G$-W, c. 50, p. 103.

${ }^{23}$ Gregory the Great, Dialogi, 3, 31, p. 388: [Leuuigildus rex] Leandro episcopo, quem prius vehementer adflixerat, Reccharedum regem filium (...) commendare curavit.

${ }^{24}$ A. P. Bronisch, "Die westgotische Reichsideologie und ihre Weiterentwicklung im Reich von Asturien”, in F.R. Erkens (dir.), Das frühmittelalterliche Königtum: Ideelle und religiöse Grundlagen, Berlin, 2005 (Erg.bde RGA, 49), p. 161-189, at p. 180-181 speaks of ‘König', 'Volk', 'Spanien’ and 'Priesterschaft'.

${ }^{25}$ Toledo IV, in Concilios Hispanos (CH), dir. G. Martínez Diez/F. Rodríguez Barbero, Madrid, 1992 (La Colección Canónica Hispana, 5), p. 259.

${ }^{26}$ Toledo $\mathrm{V}$, in $\mathrm{CH}$, c. 3, p. 282: People, quos nec origo ornat nec virtus decorat, have aspired to kingship. The sententia of the fathers is: quem nec electio omnium provehit nec Gothicae gentis nobilitas ad hunc honoris
} 
throne of the realm, which it had won and could only lose by the right of conquest. ${ }^{27}$ In this sense, Isidore styled the transition from "Golden Rome, the head of the nations", who, "initially victorious, betrothed you [Hispania] to itself", to "the most flourishing people of the Goths, who in turn, after many victories all over the world, have eagerly seized you and loved you.”28 "Le peuple des Goths demeuré une gens” remained a clearly recognizable separate and privileged entity in their kingdom. ${ }^{29}$ Even though Gothic elites may well have predominantly spoken Late Latin in the seventh century, Gothic personal names remained a sign of distinction of Gothic nobles and kings. ${ }^{30}$ Only the usurper Paul in Southern Gaul attempted to seize the throne with a Latin name: perhaps one reason why among all the failed coups and usurpations this one created an unusual stir. ${ }^{31}$

This vision of unity built on the harmony of political, territorial, ethnic and religious identity was a grandiose construction, not least achieved through the rhetorical and political efforts of Leander and Isidore. We should not underestimate its impact; as Peter Brown noted: "The Visigothic kings of Spain succeeded in holding together for over a century the largest undivided political unit in seventh-century Europe. It was a remarkable achievement, maintained, in part, by intermittent outbursts of solemn words." 32 Yet after 711 it took only a few years for the kingdom and the rule of the Goths to be destroyed, territorial unity to be dissolved and Christian hegemony removed. ${ }^{33}$ If the rule of the Goths was ultimately legitimized by their victories, a crushing defeat also meant a loss of legitimacy. No nation rose in defence. It is therefore advisable to maintain the analytical distinctions, in line with the political language of the period. Isidore distinguishes between Gothic and Roman identity, between the Spanish patria and its variety of inhabitants, and between different religious

apicem trahit, incurs the anathema should he attempt to become king. Toledo VI, in $\mathrm{CH}$, c. 17, p. 326: Nullus sub religionis habitu detonsus aut turpiter decalvatus aut servilem originem trahens vel extraneae gentis homo, nisi genere Gotus et moribus dignus, provehatur ad apicem regni. Both clauses are ambiguous - does it mean that no man from a foreign people can become king unless he is a Goth, or nobody unless a Goth? Hispano-Romans are not explicitly excluded here, unless they are servants or clerics, but Gothic identity is highlighted as a key criterium.

${ }^{27}$ W. Pohl, "Regnum und gens”, in id./V. Wieser (dir.), Der frühmittelalterliche Staat - Europäische Perspektiven, Wien, 2009, p. 435-450.

${ }^{28} H G-W$, Prologue (De laude Spaniae), p. 82.

${ }^{29}$ Fontaine, Isidore, p. 375.

${ }^{30}$ D. Claude, "Visigoths and Hispano-Romans in the Seventh Century", in W. Pohl/H. Reimitz (dir.), Strategies of Distinction: the Construction of the Ethnic Communities, 300-800, Leiden, 1998, p. 117-230, at p. 120-122; Kampers, Geschichte der Westgoten, p. 272-278; R. Wright, "Linguistic and Ethnic Identities in the Iberian Peninsula (400-1000 A.D.)”, in W. Pohl/B. Zeller (dir.), Sprache und Identitäten im frühen Mittelalter, Vienna, 2012, p. 99-108.

31 Julian, Historia Wambae, c. 2, dir. J. N. Hillgarth, Sancti Iuliani Toletanae Sedis Episcopi Opera, Pars I, Turnhout, 1976, p. 218; Insultatio vilis storici in tyrannidem Galliae, ibid., pp. 245-249. See also M. de Jong, “Adding insult to injury: Julian of Toledo and his 'Historia Wambae'”, in P. Heather (dir.), The Visigoths from the migration period to the seventh century. An ethnographic perspective, Woodbridge, 1999, p. 373-402; M. Lester, "The Ties that Bind: Diagnosing Social Crisis in Julian of Toledo’s Historia Wambae”, in H. Reimitz/G. Heydemann (dir.), Historiographies of Identity: Post-Roman Multiplicity and New Political Identities, forthcoming.

${ }^{32}$ P. Brown, The Rise of Western Christendom, 3rd ed., Oxford/Malden, 2013, p. 366.

${ }^{33}$ For a recent reflection on the possible reasons for this quick collapse, see J. Arce Martínez, "The Visigoths in Spain: Old and New Historical Problems”, in W. Pohl/V. Wieser (dir.), Der frühmittelalterliche Staat Europäische Perspektiven, Wien, 2009, p. 31-42. One of his main points is: "Without the church, there is no regnum" (p. 40). 
options and their political impact. His distinctions are not the same as ours; to understand his views, we can and should use our own conceptual tools. Yet at the same time we should historicize our concepts and ask how they relate to the ways in which Isidore perceived his world.

Isidore's Etymologiae offer one of the most elaborate reflections on the meaning of ethnicity in Late Antiquity and the Early Middle Ages. ${ }^{34}$ Only a few other authors, such as Cassiodorus (in his commentary on the Psalms), provide similar insights into the concepts behind the often opaque semantics of terms such as gens, natio, populus. ${ }^{35}$ Book IX of the Etymologies provides a general introduction, in particular on the relationship between gentes and languages, and then a long list of ethnonyms with their etymological explanations. ${ }^{36}$ According to Isidore's approach, the deeper meaning of the names, inmutata vocabula, ${ }^{37}$ and therefore also of the phenomenon indicated by the name lay in its origins. Ethnonyms, as Marc Reydellet has argued, offered a deeper clue to Isidore than the origo gentis. ${ }^{38}$ A few general observations can easily be made. First, the section IX.2, De gentium vocabulis, is almost the only systematic list of named social groupings in the work, apart from the list of heresies (VIII.4-5) and that of the 'monstrous races' (XI.4). There are no lists of cities or territorial groupings, and the implication is clear: humans can first of all be distinguished by their gens, which also determines the political landscape: each people had its own kingdom in its time, regnum universae nationes suis quaeque temporibus habuerunt. ${ }^{39}$ The rather exhaustive list given by Isidore allows tracing his criteria of what a gens is, and what it is not. Most of the names that he lists also correspond to our concepts of ethnicity, or perhaps, tribal units.

Although many names come from ancient historiography or ethnography, the Old Testament provides the main conceptual tools for understanding the meaning of a world of gentes. The first section is built on the biblical genealogy of peoples from the sons of Noah, which remains structured by generations as long as it deals with biblical peoples. More contemporary names are only grouped according to their distant origins from Sem, Japhet or Ham, so that the genealogical grid slowly fades out. That both Goths and Romans were descended from Japhet betrays no sense of a special relation between them. Rather, it links both to biblical history through Japhet as the prefiguration of the people who would believe in

\footnotetext{
${ }^{34}$ Cf. J. Henderson, The Medieval World of Isidore of Seville. Truth from Words, Cambridge, 2007, esp. p. 121132.

${ }^{35}$ G. Heydemann, "Biblical Israel and the Christian gentes: Social Metaphors and the Language of Identity in Cassiodorus's Expositio psalmorum”, in W. Pohl/G. Heydemann (dir.), Strategies of Identification: Ethnicity and Religion in Early Medieval Europe, Turnhout, 2013, p. 143-208.

${ }^{36}$ See also the Introduction to Isidorus Hispalensis, Etymologiae IX, dir. M. Reydellet, Paris, 1984, p. 1-21.

${ }^{37}$ Isidore, Etymologiarum sive Originum libri XX (Etym), dir. W. M. Lindsay, Oxford, 1911, 9.2.133; for the English translations used in this paper see The Etymologies of Isidore of Seville, dir. S. A. Barney, Cambridge, 2006.

${ }^{38}$ Fontaine, Isidore, p. 283-296; Reydellet, “Introduction”, p. 1-18; Henderson, The Medieval World.

${ }^{39}$ Etymologiae, 9.23.3. For Isidore's view that a gens should have a king, see A. H. Merrills, History and Geography in Late Antiquity, Cambridge, 2005, p. 177.
} 
Christ. ${ }^{40}$ Isidore endorsed the biblical idea that peoples were derived from a common ancestor, and could thus be grouped according to their ancestral links, but he did not care to apply it to the present. Isidore's definition of gens in the introduction recurs to the traditional feature of common origin (Gens est multitudo ab uno principio orta) but opens it up to include other features, elegantly combining the element of distinction ('distinguished [...] from another nation') with that of integration ('in accordance with its own grouping'). ${ }^{41}$ The gens Gothorum thus did not necessarily share the same origin, they could also be ab alia natione secundum propriam collectionem distincta. A problem of Gothic identity was, however, raised by their language. Peoples originate from languages, as he maintains, not languages from peoples. ${ }^{42}$ But what if the language changed? That had happened to Latin; the lingua mixta, its last stage, had spread when migrants had corrupted the language with barbarisms. ${ }^{43}$ This must have had implications for the identity both of the Romans, who lost their original language, and of the Goths, who had adopted the corrupted Latin.

The information about the Goths in the Etymologies has to be seen in the context of the identifications proposed in Isidore's Histories, which results in a rather complex picture. Scythians and Goths are both mentioned in the context of biblical genealogy as putative descendants of Japhet's son Magog. ${ }^{44}$ This attribution is repeated in the context of the Italian peoples: Gothi a Magog filio Iaphet nominati putantur, de similitudine ultimae syllabae, quos veteres magis Getas quam Gothos vocaverunt; gens fortis et potentissima, corporum mole ardua, armorum genere terribilis. ${ }^{45}$ The passage goes on with a quote from Lucan about Dacians and Getes, arguing that Daci autem Gothorum soboles fuerunt, et dictos putant Dacos, quasi Dagos, quia de Gothorum stirpe creati sunt. This is one of Isidore's more farfetched etymologies, and he promptly disclaims authorship of it (putant). The whole construction is ultimately based on the Gothic histories of Cassiodorus and Jordanes, who had already identified Scythians (who are not mentioned in this passage), Getes and (unlike Orosius) Dacians with the Goths. ${ }^{46}$ Together with the Italian context of the passage, that would suggest that Isidore was referring to Ostrogothic material, although there is no hint that Isidore knew Jordanes's Getica. In any case, the distinction between Ostrogoths and Visigoths does not appear in the Etymologies. There is no mention of the Goths among the peoples of

\footnotetext{
${ }^{40}$ U. Nagengast, Gothorum florentissima gens. Gotengeschichte als Heilsgeschichte bei Isidor von Sevilla, Frankfurt/M., 2011, p. 209.

${ }^{41}$ Isidore, Etymologiae, 9.2.1. See also Reydellet, Etymologiae, p. 40-42; W. Pohl, "Strategies of Identification”; id., "Telling the Difference: Signs of Ethnic Identity”, in W. Pohl/H. Reimitz (dir.), Strategies of Distinction: the Construction of the Ethnic Communities, 300-800, Leiden, 1998, p. 17-69, at p. 23-24; H.-W. Goetz, "Gens: terminology and perception of the 'Germanic' peoples from late Antiquity to the early Middle Ages”, in R. Corradini/M. Diesenberger/H. Reimitz (dir.), The Construction of Communities in the Early Middle Ages: Texts, Resources and Artefacts, Leiden, 2003, p. 39-64 (pp. 44-45); and J. D. Adams, "The political grammar of Isidore of Seville”, in Arts liberaux et philosophie au moyen âge: IVe congrès international de philosophie médievale, Paris, 1969, p. 763-775.

${ }^{42}$ Isidore, Etymologiae, 9.1.14.

${ }^{43}$ Isidore, Etymologiae, 9.1.7: Mixta, quae post imperium latius promotum simul cum moribus et hominibus in Romanam civitatem inrupit, integritatem verbi per soloecismos et barbarismos corrumpens.

${ }^{44}$ Isidore, Etymologiae, 9.2.27: Magog, a quo arbitrantur Scythas et Gothos traxisse originem.

${ }^{45}$ Isidore, Etymologiae, 9.2.89.

${ }^{46}$ Jordanes, Getica, dir. T. Mommsen, MGH AA, 5,1, Berlin 1882, p. 53-138, at p. 61-66; Orosius, Historiarum adversum paganos libri VII, dir. C. Zangemeister, Vienna, 1882, (CSEL, 5,1), 2, 53, p. 9, only hints to territorial succession: Dacia ubi et Gothia.
} 
Spain, who receive rather extensive treatment. The Scythians appear in other contexts without reference to the Goths, for instance, as gens antiquissima semper habita, related to the Amazons, Parthians, Bactrians, Massagetae, and Albanians. ${ }^{47}$

On the whole, the somewhat dispersed Gothic identifications in the Etymologies correspond with those in the Gothic History. ${ }^{48}$ Yet it has to be noted that only the second, more extended version of the History offers this information. The briefer version that ends with the death of Sisebut in 620 or 621 does not contain the Laus Spaniae, the Recapitulatio, and omits much of the beginning. ${ }^{49}$ Roger Collins has argued that much of it may go back to the slightly earlier brevi stilo historiola de iis quae temporibus Gothorum in Hispaniis actae sunt by Maximus of Zaragoza that Isidore mentions in his 'De viris illustribus. ${ }^{50}$ By contrast, that also means that these additions in the later version stand out as Isidore's own text within his works that are otherwise mostly derivative, among them, the initial passages about Gothic origins. The short version simply begins: Gothorum antiquissimum esse regnum certum est, quod ex regno Scytharum est exortum. He goes on with a quote from Orosius about the Scythians also found in the longer version ("These were the ones that Alexander himself said should be avoided, the ones that Pyrrhus feared, the ones that made Caesar shudder"). ${ }^{51}$ Unlike the longer version, the shorter one says that they had been ruled by kings from the beginning, "but because they were not noted in the chronicles, they are unknown". ${ }^{52}$ Only when they began to exercise their virtue on the Romans were they mentioned in the Histories. But in fact the first Gothic king mentioned in both versions of the Histories is the Gothic iudex Athanarich in the fourth century CE, very much unlike Jordanes' Getica which presents an eclectic line-up of Scythian, Getic and Dacian kings, ancestors of the Amal dynasty and third-century Gothic leaders. ${ }^{53}$

The longer version of Isidore's History, written around the same time as the Etymologies were finished, also contains the results of Isidore's research on the origins of the Goths: "The people of the Goths is a very ancient one. Some suspect that they originated from Magog, son of Japhet, on the basis of the similarity of the last syllable, or they conclude the same from the prophet Ezechiel." ${ }^{54}$ Two changes from the short version can be noted. First, Isidore does not speak of a regnum anymore, but of a gens Gothorum. And second, the Scythians are replaced

\footnotetext{
${ }^{47}$ Isidore, Etymologiae, 9.2.44 and 62-66.

${ }^{48}$ For the Gothic History (also called Origo Gothorum), see Wolf, Conquerors, p. 11-24; Merrills, History and Geography, p. 171-226; Wood, The Politics of Identity.

${ }^{49}$ See HG-M, Prologue (De laude Spaniae), p. 267-268 and c. 66-70, p. 292-295.

${ }^{50}$ Isidore, De Viris Illustribus, dir. C. Merino, Salamanca, 1964, 33, p. 153; R. Collins, "Isidore, Maximus and the Historia Gothorum”, in A. Scharer/G. Scheibelreiter (dir.), Historiographie im frühen Mittelalter, Wien, 1994, p. 345-358, at p. 350 and p. 355.

${ }^{51} H G-M$, c.1-2, p. 268; HG-W, p. 83; Orosius, Historiae 1.16.2, p. 28, where this phrase is explicitly applied to the Getae illi qui nunc et Gothi, and is placed in the context of a history of the Amazons, being the wives of the Scythians, which goes unmentioned in Isidore.

52 The later version of the History claims that per multa quippe retro saecula ducibus usi sunt, postea regibus. The earlier version corresponds to the information in both versions of Isidore's Chronicle (p. 26-27) that the regnum Scitarum originated under Seruch, before that of the Egyptians and the Assyrians.

${ }^{53}$ Athanarich: H. Wolfram, Die Goten, 5th ed., München, 2009, p. 103; Gothic kings: Jordanes, Getica, p. 66-92.

${ }^{54}$ HG-M, c.1, p. 268: Gothorum antiquissimam esse gentem [certum est]: quorum originem quidam de Magog Iafeth filio suspicantur a similitudine ultimae syllabae; et magis de Ezechiele propheta id colligentes.
} 
by a reference to the biblical genealogy of peoples (Gen. 10:2). Based on Jerome's commentary on Genesis, Magog can be linked directly to the Goths. ${ }^{55}$ Unlike in the Etymologies, Magog explicitly carries an apocalyptical connotation here by the reference to Ezekiel 38-39 (where Magog is Gog's land). Remarkably, however, and as in the Etymologies, Isidore leaves out the etymologically more straightforward direct (and current) identification of the Goths with the apocalyptic riders of Gog themselves in Ezechiel or the Apocalypse. ${ }^{56}$ There is an implication that the Goths can be understood as divine punishment, but it is rather subdued. In the seventh-century Spanish Church, there was a surprising hesitation to accept the Apocalypse as part of the biblical canon, so that Toledo IV threatened clerics who refused to accept and preach it with excommunication. ${ }^{57}$ The Recapitulatio at the end of Isidore's History reiterates the descent from Magog, but takes up the common identification with Scythians and Getae again: the Goths "have been proved to have a common origin with the Scythians. That is why they are not much different in name: with one letter changed and one removed, 'Getae' becomes 'Scythae'.,58

The Recapitulatio contains much of the often-cited praise of the Goths that won Isidore a reputation as a die-hard propagandist of the Gothic cause; Isabel Velázquez even remarked: "In my view, the Recapitulatio is the counterpoint to reality." 59 The text revolves around their military prowess and their many victories, so that "all the peoples of Europe feared them (...) the Alans were extinguished by the strength of the Goths (...) the Suevi now experienced the danger of extermination at the hands of the Goths (...) the liberty of the Goths has come about more through battle than petitions of peace.” ${ }^{\circ 0}$ A Gothic warrior might indeed be flattered by these and other passages. To the rest of the population, Isidore explains rather why they had to serve the Goths: "Rome itself, the conqueror of all peoples, submitted to the yoke of captivity and yielded to Gothic triumphs: the mistress of all nations served them like a handmaid.”61 Remarkably, Isidore did not underline that these victories were God-given: where John of Biclaro ascribes Reccared's major victory against the Franks after Toledo III to God's intervention ("Not unworthily is God praised in our own times for having intervened in this battle") and compares it to the triumph of Gideon, Isidore replaces all references to divine grace in his source by "no victory of the Goths in Spain was greater or even comparable."62

The role of Rome in the History is complex; the Empire can be considered as a role model and opponent at the same time. Throughout the History, Isidore attaches importance to

\footnotetext{
55 Jerome, Quaestiones hebraicae in libro Geneseos, dir. P. de Lagarde, Turnhout, 1959 (CCSL, 72), 18-22, p. 11.

${ }^{56}$ Isidore only mentions them in a kind of disclaimer: Retro autem eruditi eos magis Getas quam Gog et magog apellare consueverunt (HG-M, c.1, p. 268). Gog iste Gothus est: Ambrose, De fide ad Gratianum, dir. C. Markschies, Turnhout, 2005 (FC, 47, 2), 2, 16, 138, p. 105.

${ }^{57}$ Cf. A. Merrills, "Comparative histories: the Vandals, the Sueves and Isidore of Seville”, in R. Corradini/R. Meens/C. Pössel/P. Shaw (dir.), Texts and Identities in the Early Middle Ages, Vienna, 2006, p. 35-46, at p. 41. Toledo IV, c. 17, p. 205.

${ }^{58}$ HG-W, c. 66, p. 108. Cf. J. R. Carbó Garcia, “Godos y Getas en la historiografia de la Tarda Antigüedad y del Medioevo”, in Studia Historica, Studia Antiqua 22, 2004, p. 179-206.

${ }^{59}$ Velázquez, "Pro patriae”, p. 195.

${ }^{60} \mathrm{HG}-\mathrm{W}$, c. $66-70$, p. $108-110$.

${ }^{61} H G-W$, c. 67, p. 109.

${ }^{62}$ John of Biclaro, Chronicle, trans. Wolf, Conquerors, p. 57-78, at 92, p. 77; HG-W, c. 54, p. 104.
} 
peaceful relations between Goths and Romans. The Gothic king Wallia, for example, is praised as disposed to peace by divine providence because of his treaty with the Roman Emperor Honorius. ${ }^{63}$ The idea of the Roman Empire as the predominant power-at least in former days - is expressed by phrases like Roma caput gentium, Roma victrix omnium populorum or urbs cunctarum gentium victrix. ${ }^{64}$ However, these phrases, which rely on the military strength of the Roman Empire, are counterbalanced by the strength of the gens fortissima: Interpretatio autem nominis eorum in lingua nostra tecti quod significatur fortitudo: et re vera. Nulla enim gens in orbe fuit, quae Romanum imperium adeo fatigaverit. ${ }^{65}$ At the end of the Laus Spaniae, Isidore explicitly states that the Goths had replaced the Empire by their victories, "secure in the good fortune of empire". It is a very diligent use of the word 'imperium': the opes largae imperii can simply mean the benefits of secure rule, but the phrase also implies that the Goths succeeded the empire in Spain. ${ }^{66}$ Isidore's Chronicle, which likewise came down to us in two different versions (the first one dates from around the year 616, the second one in 626), provides further evidence for the refutation of Roman supremacy. Unlike many early medieval historians, Isidore of Seville does not build his chronicle on the model provided by Eusebius/Jerome, but explicitly applies Augustine's conception of the six aetates mundi for the first time to a world chronicle, instead of building on the idea of the succession of empires, which would imply that the era of Rome as the last world empire continued. ${ }^{67}$

Like in Gregory of Tours, provincial Roman identity is no issue in the History. Whereas in the beginning, the term Romani covers the inhabitants of the whole Roman Empire, it is subsequently more and more reduced to the Byzantines in the East and the Eastern Roman military forces in Spain (milites). On no occasion does the term Romani describe the inhabitants of the former provinces. The collective term Spani is used only once. ${ }^{68}$ Otherwise, particular groups of the population of the peninsula are mentioned. The Goths, or the gens Gothica, act, they invade, attack, defeat, kill their king or raise a new one, gather in assembly, record the statutes of their laws, and abjure the false teaching of Arius. Unlike Vandals and Suebi, they are never characterized as wild and uncivilized or called barbarians. It is interesting that in Isidore's own lifetime, Gothic agency almost disappears from the text; now the focus is mostly on the actions of kings, who are only sometimes styled as reges Gothorum. Suinthila is lauded as the first king to rule totius Spaniae intra oceani fretum monarchiam regni. ${ }^{69}$ The complicated formula shows that this was not simply a Spanish

\footnotetext{
${ }^{63} H G-M$, c. 21, p. 276.

${ }^{64}$ HG-M, Proloque (De laude Spaniae), p. 267; c. 67, p. 294; c. 15, p. 273.

${ }^{65} H G-M$, c. 2, p. 268. The provided interpretation of the Gothic name is another connection to Magog that goes back to Jerome who interprets the name Magog as follows: magog quod $\delta \tilde{\omega} \mu \alpha$ (id est tectum) uel de domate (hoc est de tecto). Jerome, Liber interpretationis hebraicorum nominum, dir. P. de Lagarde, Turnhout, 1959 (CCSL, 72), p. 68.

${ }^{66}$ Cf. W. Drews, “Goten und Römer als Gegenstand der Historiographie bei Isidor von Sevilla”, in Saeculum, 53,1, 2002, p. $1-20$, at p. 14.

${ }^{67}$ Reydellet, "Intentions idéologiques”; J. Wood, "Heretical Catholics and Catholic Heretics: Isidor of Seville and the Religious History of the Goths”, in D. Hook (dir.), From Orosius to the Historia Silense. Four Essays on the Late Antique and Early Medieval Historiography of the Iberian Peninsula, Bristol, 2005, p. 17-50.

${ }^{68}$ H.-J. Diesner, Isidor von Sevilla und seine Zeit, Stuttgart, 1973, p. 67-68. HG-M, c. 73, p. 296.

${ }^{69}$ HG-M, c. 62, p. 292.
} 
kingdom, but "the sole rule of a kingdom of all Spain between the oceans". The Acts of the Councils variously describe the extent of the kingdom and its Church using the names Spania(e), Gallia and also Gallicia. ${ }^{70}$

The grand design of Isidore's History of the Goths - a prosperous Spania unified both in Catholic doctrine and by Gothic rule-is also reflected in the Acts of the two major Church Councils held during his lifetime: Toledo III in 589 and Toledo IV in 633. The Third Council of Toledo, in which Isidore's brother and predecessor Leander played a key role, sanctioned the conversion of the Goths to the Catholic creed. ${ }^{71}$ The conversion was confirmed by the professio fidei and the signatures "of all bishops and the seniors of the entire people of the Goths, totius gentis Goticae seniorum”, which in fact meant eight formerly Arian bishops with Gothic names, five Gothic viri illustres, and is bolstered by the wholesale remark similiter et omnes seniores Gotorum subscripserunt. ${ }^{72}$ In comparison with the almost 60 catholic bishops present, the eight homoian renegades seem few, and none of them represented a metropolitan see; the majority of the Arian bishops obviously had not come, or not converted. ${ }^{73}$ The subscriptions also show a surprisingly clear distinction between the Gothic Arian bishops, who expressed their identity in their (however Latinized) Gothic names, and the Catholic episcopate among which only one Ermaricus had a clearly Gothic name. The boundaries between the Gothic and the Hispano-Roman elites still seem to have been quite well demarcated, which the rhetoric of inclusion deployed at the council sought to remedy. Leander's homily included at the end of the Acts of Toledo III goes beyond the bounds of Christian teaching in its last sentence that induces the fathers to pray for the transcendental glory of the kingdom and the gens: Deum precibus adeamus, ut regnum et gens, quae Christum glorificavit in terris, glorificetur ab illo non solum in terris, sed etiam in caelis. Similarly, the Acts of Toledo IV expressed the hope that "in the eternal kingdom, he who happily rules on earth will reign without end." ${ }^{74}$ These statements projected the separate existence of the gens Gothorum and the rule of its kings into the kingdom of heaven, as if to assure the Goths that after the loss of their separate church the Catholic bishops would cherish their distinctive identity.

Isidore proved as versatile in dealing with the Gothic regime as his brother, and ingratiated himself with successive kings, most of whom had come to power by a coup, not least by flattery. Only rarely do we find traces of critique in Isidore's work, for instance, of Sisebut's forced conversion of the Jews (but only in the second version of the History updated after the king's death), or of the Gothic destruction of Cartagena, from where Isidore's family originated. ${ }^{75}$ The very succinct and polished character of Isidorian historiography hardly allows tracing implicit critique or hidden contradictions. But he was not an opportunist. As

\footnotetext{
${ }^{70}$ Martin, La géographie, p. 84.

${ }^{71}$ Toledo III, in CH, p. 49-160.

${ }^{72}$ Toledo III, in CH, p. 98-99.

${ }^{73}$ See also Stocking, Bishops, p. 61.

${ }^{74}$ Toledo III, p. 159. Cf. Toledo IV, p. 259: Corroboret Christi gloria regnum illius [i.e. Sisenand] gentisque Gothorum in fide catholica (..) protegat illum (...) summi Dei gratia, et post praesentis regni gloriam ad aeternum regnum transeat ut sine fine regnet qui intra seculum feliciter imperat.

${ }^{75}$ Isidore, Etymologiae, 15.1.67; Fontaine, Isidore, p. 369.
} 
Jacques Fontaine has shown, Isidore's cultural project and prolific writing was intended to achieve consensus in the kingdom and make Gothic elites aware of their responsibilities. ${ }^{76}$ Isidore acted as a cultural broker, to use an expression employed by Helmut Reimitz for some of the Latin authors in early medieval Gaul. He offered integration while maintaining difference, which provided him with the space to negotiate. ${ }^{77}$

The Fourth Council of Toledo, under the guidance of Isidore (who signed its minutes first), strove further to establish a unified vision of Gothic Spain. ${ }^{78}$ In the last canon, the bishops expressed their worries about "the force of our kings and the stability of the gens Gotorum". ${ }^{79}$ To quell further usurpation, they introduced several measures and threatened all rebels with the anathema, that is, quicumque amodo ex nobis vel cunctis Spaniae populis quolibet tractatu vel studio sacramentum fidei suae, quod pro patriae gentisque Gotorum statu vel conservatione regiae salutis pollicitus est, violaverit. ${ }^{80}$ This means that the entire population of Spain, consisting of different peoples (populi), had sworn an oath of fidelity to the patria, to the ruling gens Gothorum, and for the wellbeing of the king. ${ }^{81}$ Violation of this oath provided a reason to punish secular rebellion according to canon law: sacrilegium quippe esse si violetur a gentibus regum suorum promissa fides. ${ }^{82}$ Quite explicitly, the problem is attributed to the disloyalty of the gentes, not of the population in general. The phrasing of this and several similar passages demonstrates a complex political concept which included, but distinguished between the territory and its different peoples, among them, the gens Gothorum to which all the others had to swear allegiance. The monarchy and the person of the king were also conceptually separated. After the death of the king, a successor had to be elected by the bishops, and by the Gothic nobles as representatives of the gens, so that no patriae gentisque discidium should arise. ${ }^{83}$ Once again, an ideal of concord was projected, which should concern both the power relations within the Gothic warrior elite, and the balance between episcopal authority and the king's rule.

Successive councils of Toledo insisted with increasing exasperation on the enforcement of legitimate succession by canonical sanctions; Chindaswinth's edict complemented them by harsh secular penalties. ${ }^{84}$ Leander's and Isidore's ambitious project of establishing social cohesion by moral exhortation, by the provision of cultural resources and by ensuring God's grace for gens and kingdom, and if necessary, by “coercive consensus” ${ }^{85}$, did not achieve its

\footnotetext{
${ }^{76}$ Fontaine, Isidore; see also Stocking, Bishops, p. 13.

${ }^{77}$ H. Reimitz, "The historian as cultural broker in the late and post-Roman West”, in Cultural transfer in the Mediterranean, 5th to 9th centuries, Bangor, forthcoming; id., History, Frankish Identity and the Framing of European Ethnicity, 550-850, Cambridge, forthcoming; see also Wood, "Religiones and gentes”, p. 158-163.

${ }^{78}$ Velázquez, "Pro patriae”, esp. p. 196-205.

${ }^{79}$ Toledo IV, c. 75, p. 248.

${ }^{80}$ Toledo IV, p. 253. Cf. Velázquez, "Pro patriae”.

${ }^{81}$ S. Esders, “'Faithful believers'. Oaths of Allegiance in Post-Roman Societies as Evidence for Eastern and Western 'Visions of Community”, in W. Pohl/C. Gantner/R. Payne (dir.), Visions of Community in the PostRoman World. The West, Byzantium and the Islamic World, 300-1100, Farnham, 2012, p. 357-374.

${ }^{82}$ Toledo IV, c. 75, p. 250.

${ }^{83}$ Toledo IV, c. 75, p. 251: defuncto in pace principe primatus totius gentis cum sacerdotibus successorem regni consilio communi constituant.

${ }^{84}$ Velázquez, "Pro patriae”, p. 205-215.

${ }^{85}$ Stocking, Bishops, p. 24-25.
} 
goals. Remarkably, Isidore's (and the councils') rhetoric of consensus had not removed the ethnic distinctiveness of the Goths. In contemporary political discourse, the gens Gothorum was juxtaposed with Spania, with the kingdom and the Church as mechanisms of cohesion. Besides, these were 'the' Goths, not Visigoths. "Ethnic discourse reaches its zenith" at Toledo IV, as Isabel Velázquez has argued. ${ }^{86}$ In reality, of course, such boundaries were permeable, for instance for Romans with political ambitions (King Ervig was the son of a Byzantine immigrant), or for Goths who sought clerical careers. ${ }^{87}$ Spain and the kingdom consisted of many gentes or populi; in the latter term, the Hispano-Romans could be more smoothly included, although the terms were often used rather indiscriminately. Reccared's royal title used in his confirmation of Toledo III indicates that ultimately his kingdom was little more than the sum of its subjects: Reccaredus rex universorum sub regni nostri potestae consistentium. ${ }^{88}$ In that sense, Spani was only a loose collective label. What the Spanish had in common, as Isidore observes, was that "subjected, the Roman soldier serves the Goths, whom he sees being served by many peoples and by Spain itself”. ${ }^{89}$ The bishops thought of themselves as representatives of the Spanish majority, just as the Gothic seniores or primati represented the gens Gothorum. These noble Goths had the prerogative of ruling 'their' kingdom. To what degree ethnic identity served as an internal means of cohesion among the Gothic elites does not become clear from contemporary sources. Isidore was only moderately interested in the modes of identification inside the gens Gothorum, and we have little clue what origin myths, heroic legends, kinship networks, formal assemblies or grades of nobility may have meant to them. ${ }^{90}$ In his texts, and in those of the councils, the gens served as a symbolic unit, a time-honoured aggregate of military force to whom the exercise of power had to be entrusted. He used the whole repertoire of ancient and biblical ethno-history to affirm, legitimize and project a model of ethnic rule that could stabilize the precarious powerbalance within the Gothic elite, and thus, in the kingdom.

The conversion of the Goths had drawn the catholic bishops much closer into the orbit of royal power, upon which they tried to exert their influence. Yet, “Toledo IV's effort at institutionalizing conciliar governance” to supplement or even supervise the rather conflictual Gothic regime ultimately proved a failure. ${ }^{91}$ The logic of violent struggles for the throne seemed inescapable: the morbus Gothorum, as the Fredegar-Chronicle called it, the habit of killing their kings. ${ }^{92}$ Isidore knew from history that the rule of war-like gentes (and the Romans were no exception) had always created problems. We can assume that like Orosius, he had hoped that true Christian faith and God's grace could make things better, and he had striven to contribute by prayer, writing, education, preaching, exhortation and canonical

\footnotetext{
${ }^{86}$ Velázquez, "Pro patria”, p. 204.

${ }^{87}$ Claude, "Visigoths and Hispano-Romans".

${ }^{88}$ Toledo III, p. 132.

${ }^{89} \mathrm{HG}-\mathrm{W}$, c. 70, p. 110 . See also Hillgarth, The Visigoths, p. 37.

${ }^{90}$ D. Claude, Adel, Kirche und Königtum im Westgotenreich, Sigmaringen, 1971, offers a reliable synthesis of traditional research which specifically looked for such 'Germanic' traits, but found little of them in the evidence. ${ }^{91}$ Stocking, Bishops, p. 25.

${ }^{92}$ Chronicarum quae dicuntur Fredegarii Scholastici libri IV, dir. B. Krusch, MGH SS rer. Merov., 2, Hannover, 1888, 4, 82, p. 163; W. Pohl, “Morbus Gothorum. Nachfolgeprobleme bei den Westgoten”, in S. Diefenbach/U. Gotter/W. Havener (dir.), The Arts of Succession, forthcoming.
} 
sanctions. His rhetoric remained almost untainted over the years. We do not know whether he also maintained his expectations that the ways of the Goths could really be amended. 